Review

\title{
Green Carbon Nanostructures for Functional Composite Materials
}

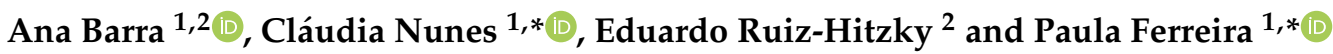 \\ 1 Department of Materials and Ceramic Engineering, CICECO-Aveiro Institute of Materials, \\ University of Aveiro, 3810-193 Aveiro, Portugal; abarra@ua.pt \\ 2 Materials Science Institute of Madrid, CSIC, c/Sor Juana Inés de la Cruz 3, 28049 Madrid, Spain; \\ eduardo@icmm.csic.es \\ * Correspondence: claudianunes@ua.pt (C.N.); pcferreira@ua.pt (P.F.); Tel.: +351-234-370200 (P.F.)
}

Citation: Barra, A.; Nunes, C.; Ruiz-Hitzky, E.; Ferreira, P. Green

Carbon Nanostructures for

Functional Composite Materials. Int. J. Mol. Sci. 2022, 23, 1848. https:// doi.org/10.3390/ijms23031848

Academic Editor: Valentina Villari

Received: 29 December 2021

Accepted: 31 January 2022

Published: 6 February 2022

Publisher's Note: MDPI stays neutral with regard to jurisdictional claims in published maps and institutional affiliations.

Copyright: (C) 2022 by the authors. Licensee MDPI, Basel, Switzerland. This article is an open access article distributed under the terms and conditions of the Creative Commons Attribution (CC BY) license (https:// creativecommons.org/licenses/by/ $4.0 /)$.

\begin{abstract}
Carbon nanostructures are widely used as fillers to tailor the mechanical, thermal, barrier, and electrical properties of polymeric matrices employed for a wide range of applications. Reduced graphene oxide (rGO), a carbon nanostructure from the graphene derivatives family, has been incorporated in composite materials due to its remarkable electrical conductivity, mechanical strength capacity, and low cost. Graphene oxide (GO) is typically synthesized by the improved Hummers' method and then chemically reduced to obtain rGO. However, the chemical reduction commonly uses toxic reducing agents, such as hydrazine, being environmentally unfriendly and limiting the final application of composites. Therefore, green chemical reducing agents and synthesis methods of carbon nanostructures should be employed. This paper reviews the state of the art regarding the green chemical reduction of graphene oxide reported in the last 3 years. Moreover, alternative graphitic nanostructures, such as carbons derived from biomass and carbon nanostructures supported on clays, are pointed as eco-friendly and sustainable carbonaceous additives to engineering polymer properties in composites. Finally, the application of these carbon nanostructures in polymer composites is briefly overviewed.
\end{abstract}

Keywords: reduced graphene oxide; clays; hydrothermal carbons; supported carbons; polymer composites

\section{Introduction}

The discovery of graphene, a two-dimensional (2D) material composed of $\mathrm{sp}^{2}$ carbon monolayer arranged into a hexagonal network, had a tremendous impact in carbon materials research [1]. Graphene was isolated from graphite by mechanical exfoliation with an adhesive tape for the first time in 2004 by Geim et al. [2]. The relevance of this work was recognized by the attribution of the Nobel Prize in Physics in 2010. The ideal single-layer graphene has exceptional physical properties, such as ultrahigh charge-carrier mobility (200,000 $\mathrm{cm}^{2} \mathrm{~V}^{-1} \mathrm{~s}^{-1}$ at room temperature), high Young's modulus ( $\left.\sim 1.0 \mathrm{TPa}\right)$, high specific surface area (theoretical value of $2630 \mathrm{~m}^{2} \mathrm{~g}^{-1}$ ), absorption of only $2.3 \%$ of visible light, and high thermal conductivity $\left(\sim 500 \mathrm{~W} \mathrm{~m}^{-1} \mathrm{~K}^{-1}\right)$. Therefore, graphene is a promising material for many distinct areas, such as energy, medicine, or electronics [3-5].

Eighteen years after the graphene isolation, the 2D carbon materials research is greatly developed. However, the word "graphene" has been widely misused to designate distinct 2D carbon materials when it should be reserved for the graphene sheets [1]. The intense research around graphene led to a diversification of the synthesis methods and graphene materials synthesized. Different synthesis techniques produce graphene derivatives with distinct features, varying in number of layers, lateral size, yield, type of defects, and consequently, properties [6].

Graphene derivatives, including graphene nanoplatelets (GNP) [7], graphene oxide (GO) [8], and reduced graphene oxide ( $\mathrm{rGO}$ ) [9], are suitable fillers for the development of polymer composites. However, synthesis challenges associated with difficulties to 
scale up turn the graphene derivatives expensive nanomaterials [10]. Besides, the use of toxic chemicals prevents their safe application in target areas, such as the food packaging industry and the biomedical field [11]. In this context, sustainable synthesis methods to produce green graphene derivatives avoiding toxic chemicals have been developed. The production of rGO using green chemical reductants to replace the toxic ones is a major example. Furthermore, the development of alternative carbon nanostructures using natural feedstock as carbon precursors encompasses diverse sustainable strategies to address these issues.

This review presents different approaches to prepare sustainable carbon nanostructures suitable for polymer-based composites. The recent advances regarding the green chemical reduction of $\mathrm{GO}$ are overviewed. The sustainable production of hydrothermal carbon nanostructures, graphitic materials derived from biomass, and graphitic materials supported on clays are highlighted. Finally, the application of these green carbon nanostructures in polymer composites is overviewed.

\section{Chemical Reduction of Graphene Oxide}

rGO is the most used 2D carbon material for the development of electrically conductive and mechanically reinforced polymer composites [3]. Graphite, constituted by graphene layers bonded by strong van der Waals forces, is the bulk starting material to synthesize rGO. First, graphite is oxidized to produce GO. After that, GO suffers a reduction step to produce rGO, as shown in Figure 1.

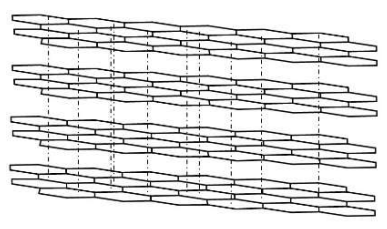

graphite

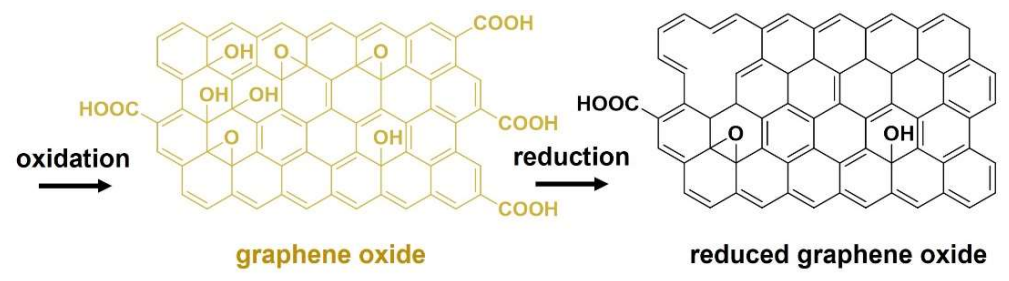

reduced graphene oxide

Figure 1. The chemical production of graphene oxide from graphite.

Hummers' method and its variations are currently the most used procedures to synthesize GO [12]. The chemical exfoliation of graphite is achieved using strong acids, as concentrated sulfuric and phosphoric acids, which promote the graphene layers' separation. The oxygenation of the separated graphene layers is accomplished using oxidants, such as hydrogen peroxide and potassium permanganate. The reduction process consists in the partial removal of oxygen functionalities present in the GO structure, namely, tertiary alcohols and epoxides attached to $\mathrm{sp}^{3}$ carbons, and hydroxyl and carboxylic groups attached to the $\mathrm{sp}^{2}$ lattice. This process converts the hydrophilic and insulator GO (yellow) into the hydrophobic and electrically conductive rGO (black) [13]. The extent of oxygen removal relies on the efficiency of the reducing agent. However, the deoxygenation is incomplete and the remnant oxygen functionalities promote the rGO dispersion and functionalization and may interact with polymers, being an advantage for the preparation of composites.

\subsection{Evaluation of the Reduction Extent}

The conversion of GO into rGO can be confirmed by different characterization techniques, such as Raman spectroscopy, X-ray photoelectron spectroscopy (XPS), and X-ray powder diffraction (XRD). Other techniques, such as Fourier-transform infrared spectroscopy (FTIR), ultraviolet-visible spectrophotometry (UV-Vis), and thermogravimetric analysis (TGA), are also useful tools.

Raman spectroscopy is a nondestructive technique employed to evaluate the structural changes that take place upon GO-to-rGO conversion. Graphene derivatives present characteristic $D$ and $G$ bands at $\sim 1355$ and $\sim 1575 \mathrm{~cm}^{-1}$, respectively. The $D$ band is activated by the presence of defects such as edges, vacancies, and grain boundaries in the carbon lattice. The $\mathrm{G}$ band corresponds to the vibration mode of $\mathrm{sp}^{2}$ carbon atoms. The intensity ratio of 
the $\mathrm{D}$ band over the $\mathrm{G}$ band $\left(\mathrm{I}_{\mathrm{D}} / \mathrm{I}_{\mathrm{G}}\right)$ is a parameter commonly used to access the level of disorder of graphene materials. The increment of $\mathrm{sp}^{2}$ graphitic domains and decrease in defect density may lead to a decrease in $\mathrm{I}_{\mathrm{D}} / \mathrm{I}_{\mathrm{G}}$ ratio [14]. However, the $\mathrm{I}_{\mathrm{D}} / \mathrm{I}_{\mathrm{G}}$ ratio of $\mathrm{rGO}$ is frequently reported to increase, which is justified if the new graphitic domains have a lower average size compared with the ones present in GO. Additionally, new defects may be introduced due to the removal of oxygen functionalities [15-17].

XPS is a powerful technique used to determine the surface chemical composition and the local chemical environment of the elements. The $\mathrm{sp}^{2} / \mathrm{sp}^{3}$ carbon hybridization is accessed through the fitting of the $\mathrm{C} 1 \mathrm{~s}$ spectrum. The quantification of carbon and oxygen atomic percentages is used to determine the $\mathrm{C} / \mathrm{O}$ ratio, which is one of the main parameters to evaluate the extent of the GO reduction $[18,19]$.

$\mathrm{XRD}$ is used to monitor the evolution of the crystalline structure and lattice parameters upon reduction. The diffractogram of GO shows a characteristic peak at around $2 \theta=10^{\circ}$ corresponding to the reflection (001), with a typical d-spacing value of $\sim 0.85 \mathrm{~nm}$, caused by the presence of oxygen between GO sheets. A small peak around $2 \theta=42^{\circ}$ corresponding to the reflection (102) can also be observed. After the reduction, the peak at $2 \theta=10^{\circ}$ disappears or becomes less intense (in cases of mild reduction), and a new peak at $\sim 2 \theta=25^{\circ}$ corresponding to the (002) reflection appears. The d-spacing associated with this reflection is commonly around $0.35 \mathrm{~nm}$, but it depends on the extent of oxygen removal from GO. Additionally, the functionalization of rGO by the reducing agent might increment this value [20].

UV-Vis spectrophotometry can be used to monitor the reduction in case of rGO dispersions with homogeneous spatial distribution of particles. GO presents a strong absorption peak at approximately $230 \mathrm{~nm}$, attributed to the $\pi-\pi^{*}$ transitions of aromatic $\mathrm{C}-\mathrm{C}$ bonds, and a weaker peak at approximately $280 \mathrm{~nm}$, assigned to the $n-\pi^{*}$ transitions of $\mathrm{C}=\mathrm{O}$ bonds. After reduction, the peak at $230 \mathrm{~nm}$ redshifts to approximately $270 \mathrm{~nm}$, suggesting the restoration of the $\mathrm{sp}^{2}$ graphene lattice [21-23].

The TGA signature of carbon materials typically presents three characteristic regions. The first region, $<100{ }^{\circ} \mathrm{C}$, is attributed to water evaporation. The second region, between 100 and $360^{\circ} \mathrm{C}$, is related to the decomposition of oxygen-containing groups. Finally, the third one, between 360 and $1000{ }^{\circ} \mathrm{C}$, is attributed to carbon combustion when TGA is performed under air flow, or degradation of unstable carbon in case of being performed under inert atmosphere. The high percentage of oxygen functional groups on the GO structure leads to a thermal degradation at lower temperatures than rGO, which allows us to distinguish both materials by TGA $[24,25]$.

\subsection{Typical Reduction Methods}

In the last few years, many innovative reduction strategies have been reported. The main approaches to reduce GO are chemical reduction [26], thermal decomposition [19], or strategies involving a combination of thermal and chemical methods [20]. Electrochemical reduction is another eco-friendly methodology, where GO is reduced in a standard electrochemical cell through the application of voltage. This method allows the simultaneous reduction and deposition of rGO into a substrate [27]. These approaches can produce rGO with high a C/O ratio and electrical conductivity. Nevertheless, thermal decomposition (typically above $500^{\circ} \mathrm{C}$ ) requires a high energy consumption, which turns difficult the scaleup process. Thus, chemical reduction is the most exploited approach for the large-scale production of rGO.

Hydrazine is pointed as the most effective chemical reducing agent, producing rGO with a high electrical conductivity. In 2007, Stankovich et al. [15] reported the reduction of GO with hydrazine hydrate at $100{ }^{\circ} \mathrm{C}$ for $24 \mathrm{~h}$. The rGO sheet aggregates presented an electrical conductivity of $2420 \mathrm{~S} \mathrm{~m}^{-1}$. In 2008, $\mathrm{Li}$ and coworkers [23] improved this reduction method, being able to produce rGO-stable water dispersions through the addition of ammonia solution to the reaction. The rGO film prepared by vacuum filtration presented an enhanced electrical conductivity of $\sim 7200 \mathrm{~S} \mathrm{~m}^{-1}$. Given these results, and despite 
its hazardous and pollutant features, hydrazine is still used as the reference reducing agent $[28,29]$.

The growing interest in rGO-based materials ignited this research field, having currently known more than 50 types of chemical reducing agents [11]. Sulfur-containing compounds [30], nitrogen-containing compounds [31], and oxygen-containing compounds [20] are categorical examples that illustrate the diverse nature of reducing agents. $\mathrm{N}$ - and $\mathrm{S}$-containing reducing agents can simultaneously reduce $\mathrm{GO}$ and produce $\mathrm{N}$ - or S-modified rGO, with particular interest in diverse rGO applications. Wang et al. [32] synthesized S-modified rGO through the reduction of GO by cystamine dihydrochloride under basic conditions at $55^{\circ} \mathrm{C}$ during $24 \mathrm{~h}$. The S-modification reinforced the interactions between rGO and rubber, and consequently improved the mechanical and thermal properties of rubber-based composites in comparison with rGO reduced with hydrazine. Zhang et al. [33] reported $\mathrm{N}$-modified rGO synthesized through a simple one-step hydrothermal reaction of $\mathrm{GO}$ in the presence of ammonium carbonate used as a chemical reductant. The N-modified rGO revealed improved electrochemical performances suitable for energy storage electrode materials.

The most effective reducing agents are commonly toxic compounds, which limit the use of rGO for food, biological, or medical applications. Therefore, many nontoxic eco-friendly reducing agents have been investigated.

\subsection{Green Chemical Reduction}

Ascorbic acid, commonly known as vitamin $C$, is one of the most used green reducing agents. The reduction of $\mathrm{GO}$ with $\mathrm{L}$-ascorbic acid at room temperature during $48 \mathrm{~h}$ achieved an electrical conductivity of $\sim 800 \mathrm{~S} \mathrm{~m}^{-1}$ [34]. Ascorbic acid also plays a role in the rGO stabilization. The oxidized ascorbic acid products can establish hydrogen bonds with the remaining oxygen-containing groups present in rGO. These interactions prevent the $\pi-\pi$ stacking between rGO sheets, which decreases the rGO agglomeration and promotes the water dispersion. After this, many green reducing strategies have been tested.

Table 1 lists the works, published in the last three years, regarding the green reduction of GO. These works are grouped into three main categories-plant extracts, bacteria, and combined methods-where a green chemical reducing agent is used along with a thermal or mechanical method. Plant extracts are the main category of green reducing agents due to their low cost, abundancy, and rich composition in natural reducing compounds. For example, eucalyptus bark aqueous extract was used to reduce GO, resulting in highly reduced few layer rGO. XPS analysis determined a significant increase in $\mathrm{C} / \mathrm{O}$ ratio from 5.06 in GO to 10.9 in rGO, pointing an efficient oxygen removal. The reduction efficiency of this extract is attributed to the high content in polyphenolic compounds present in its composition [35]. In another work, GO was reduced with Thuja orientalis seed extract. Gas chromatography with a mass spectrometry detector (GC-MS) analysis pointed alphatocopherol as the main reducing compound [36]. Syzygium samarangense ripened fruit extract was used to reduce GO, producing rGO with a $4.8 \mathrm{C} / \mathrm{O}$ ratio. The ascorbic acid and aspartic acid present in this fruit composition are behind the reducing ability of the extract [37]. Similarly, the reduction of GO with Bougainvillea glabra flower yielded rGO with a $4.6 \mathrm{C} / \mathrm{O}$ ratio due to a rich composition in caffeic, gallic, and tannic acids [21].

The reduction of GO with plant extracts is usually considered a simple process. The plant extracts can be prepared from different parts of the plant, e.g., leaves, seeds, fruits, flowers, or bark, being typically prepared by reflux. After that, the reduction of GO is typically achieved by stirring the extract with a GO solution at temperatures below $100{ }^{\circ} \mathrm{C}$ between 1 and $40 \mathrm{~h}$. Therefore, the reduction of GO with plant extracts is a simple and sustainable process. Given the diversity of plants with a rich composition in reducing compounds, the exploration of novel plant extracts to reduce GO is expected to continue during the next years.

Bacteria are another category of green reducing agents reported in the last 3 years, as shown Table 1 . The process is also simple, avoiding toxic chemicals and high energy 
consumption. GO reduction is achieved through the extracellular electron transfer from the bacterial cell to GO. Bacterial reduction can be achieved by simply placing bacteria in contact with a GO solution [38,39]. Another approach is the use of bacterial polymers. Wang et al. [40] used extracellular polymeric substances extracted from Bacillus sp. NT 10 in the presence of ammonia to convert $\mathrm{GO}$ with a $1.2 \mathrm{C} / \mathrm{O}$ ratio into $\mathrm{rGO}$ with a $3.2 \mathrm{C} / \mathrm{O}$ ratio. The reduction was attributed to the electron-rich proteins present in the bacterial extracellular polymeric substances, along with a synergetic effect of the reducing power of ammonia ions. Eco-friendly sulfur and nitrogen rGO modification can also be accomplished using bacteria. Dong et al. [41] reported a use of Desulfotomaculum sulfate-reducing bacteria to produce $\mathrm{N}$ - and S-modified rGO. A GO film was prepared by solvent casting and incubated with bacteria for a few days at $37^{\circ} \mathrm{C}$. The resulting material showed a $4.5 \mathrm{C} / \mathrm{O}$ ratio and $3.71 \%$ and $0.72 \%$ atomic percentages of nitrogen and sulfur heteroatoms, respectively. Similarly, Kalathil et al. [38] reduced GO with Geobacter sulfurreducens and acetate. The Geobacter/rGO material showed a $5.5 \mathrm{C} / \mathrm{O}$ ratio and heteroatom modification with $5 \% \mathrm{~N}$ and $<1 \%$ of $\mathrm{S}, \mathrm{P}$, $\mathrm{Fe}$, and $\mathrm{Cu}$.

The combination of chemical and physical reduction methods is a strategy to improve the extension of reduction while maintaining mild conditions, as shown in Table 1. Recently, we reported the synthesis of rGO by the hydrothermal treatment of GO in the presence of caffeic acid. Caffeic acid not only reduced rGO, but also produced carbon particles that can be used for further rGO functionalization [20]. Furthermore, $\mathrm{ZnO}$ nanostructures were grown in situ with simultaneous reduction of GO sheets by a solvothermal method using ethanol as solvent. The obtained $\mathrm{ZnO}-\mathrm{rGO}$ nanostructures can be used as functional fillers due to the antimicrobial activity of $\mathrm{ZnO}$ [42]. Narayanan et al. [25] also reported the hydrothermal synthesis of rGO using starch as reducing agent. The combination of the green chemical reduction with mechanical exfoliation (e.g., Taylor vortex flow or ball milling) is another eco-friendly strategy to synthesize rGO $[43,44]$. The green reduction of GO is a low-cost process. The selection of nonhazardous reducing agents commonly produces nontoxic and biocompatible rGO suitable to be used in biomedical or food applications $[45,46]$. For example, the $\mathrm{N}$ - and S-modified rGO film prepared by bacterial reduction was directly used to cultivate $\mathrm{MCF}-7$ breast cancer cells on top, being used as an electrochemical $\mathrm{H}_{2} \mathrm{O}_{2}$ sensor [41]. Similarly, the starch-modified rGO was biocompatible to human skin fibroblasts and hemocompatible to red blood cells [25]. In addition, the simultaneous reduction and modification of $\mathrm{rGO}$, or even the presence of the reducing agent in the final material, might be beneficial to establish chemical interactions with polymeric matrices in the preparation of composite materials. Therefore, the green rGO has promising features for the development of polymer composites avoiding toxic compounds that compromise the biological areas.

Table 1. Green chemical reducing agents used to convert GO into rGO reported in the last three years.

\begin{tabular}{|c|c|c|c|c|c|}
\hline Reductant & Conditions & $\mathrm{C} / \mathrm{O}$ ratio $^{\mathrm{a}}$ & $\mathbf{I}_{\mathrm{D}} / \mathbf{I}_{\mathrm{G}}$ & d-Spacing $(\mathrm{nm})^{b}$ & Ref. \\
\hline Elemental sulfur & $4 \mathrm{~h}, 170{ }^{\circ} \mathrm{C}$ & 13.2 & 0.97 & 0.363 & [47] \\
\hline POM $\left(\mathrm{SiW}_{12} \mathrm{O}_{40}{ }^{5-}\right)$ & $1 \mathrm{~min}$ & 6.1 & 1.13 & - & [48] \\
\hline \multicolumn{6}{|c|}{ Plant Extracts } \\
\hline Urtica dioica leaf & $\mathrm{pH} 12,1 \mathrm{~h}, 90{ }^{\circ} \mathrm{C}$ & 4.8 & 1.13 & - & [29] \\
\hline Thuja orientalis seed & $6 \mathrm{~h}, \mathrm{RT}$ & - & 0.14 & 0.355 & [36] \\
\hline \multirow{2}{*}{ Peganum harmala seed } & $1 \mathrm{~h}, 90^{\circ} \mathrm{C}$ & - & 0.94 & 0.355 & [49] \\
\hline & $\mathrm{pH} 12,1 \mathrm{~h}, 90{ }^{\circ} \mathrm{C}$ & - & 0.90 & 0.380 & [50] \\
\hline Syzygium samarangense fruit & $40 \mathrm{~h}, 60^{\circ} \mathrm{C}$ & 4.8 & 1.17 & 0.370 & [37] \\
\hline Tridax procumbens leaf & $12 \mathrm{~h}, 95^{\circ} \mathrm{C}$ & - & 1.00 & 0.360 & [45] \\
\hline Gooseberry fruit & $3 \mathrm{~h}, 95^{\circ} \mathrm{C}$ & - & 1.11 & 0.368 & [51] \\
\hline Erythrina senegalensis leaf & $3 \mathrm{~h}, 95^{\circ} \mathrm{C}$ & 6.2 & - & 0.330 & [46] \\
\hline Bougainvillea glabra flower & $5 \mathrm{~h}, 95^{\circ} \mathrm{C}$ & 4.6 & - & 0.380 & [21] \\
\hline Eucalyptus bark & $24 \mathrm{~h}, 85^{\circ} \mathrm{C}$ & 10.9 & 1.15 & 0.356 & [35] \\
\hline Capsicum annuum fruit & $8 \mathrm{~h}, 80^{\circ} \mathrm{C}$ & - & 1.30 & 0.341 & [52] \\
\hline Camellia sinensis leaf & $\mathrm{pH} 9,2 \mathrm{~h}, 120^{\circ} \mathrm{C}$ & - & 1.14 & 0.337 & [53] \\
\hline
\end{tabular}


Table 1. Cont.

\begin{tabular}{|c|c|c|c|c|c|}
\hline Reductant & Conditions & $\mathrm{C} / \mathrm{O}$ ratio $^{a}$ & $\mathbf{I}_{\mathrm{D}} / \mathbf{I}_{\mathrm{G}}$ & d-Spacing $(\mathrm{nm})^{b}$ & Ref. \\
\hline \multicolumn{6}{|c|}{ Bacteria } \\
\hline Pseudoalteromonas sp. & $24 \mathrm{~h}$ & - & 1.30 & 0.335 & [39] \\
\hline Desulfotomaculum & Few days, $37^{\circ} \mathrm{C}$ & 4.5 & 1.37 & 0.370 & [41] \\
\hline Bacillus sp. EPS & $\mathrm{pH} 8,24 \mathrm{~h} 40^{\circ} \mathrm{C}$ & 3.2 & 1.02 & 0.365 & [40] \\
\hline G. sulfurreducens/acetate & $48 \mathrm{~h}, 30^{\circ} \mathrm{C}$ & 5.5 & 1.18 & - & [38] \\
\hline Bacillus sphaericus & $48 \mathrm{~h}, 30^{\circ} \mathrm{C}$ & 2.6 & 1.17 & 0.870 & [54] \\
\hline \multicolumn{6}{|c|}{ Combined Methods } \\
\hline HTC/caffeic acid & $24 \mathrm{~h}, 180^{\circ} \mathrm{C}$ & 6.0 & 1.09 & 0.343 & [20] \\
\hline $\mathrm{HTC} / \mathrm{ZnO}$ & $\mathrm{pH} 1,24 \mathrm{~h}, 150^{\circ} \mathrm{C}$ & - & 1.32 & - & [42] \\
\hline HTC/starch & $\mathrm{pH} 9,15 \mathrm{~min}, 120^{\circ} \mathrm{C}$ & 3.6 & 1.03 & 0.378 & [25] \\
\hline HTC / P. amboinicus leaf & $12 \mathrm{~h}, 120^{\circ} \mathrm{C}$ & - & 1.30 & 0.360 & [55] \\
\hline TVF/ascorbic acid & $\mathrm{pH} 10,0.5 \mathrm{~h}, 95^{\circ} \mathrm{C}$ & 6.2 & 1.32 & 0.390 & [43] \\
\hline $\mathrm{BM} / \mathrm{Zn}$ & $6 \mathrm{~h}, \mathrm{RT}$ & 8.9 & 1.32 & - & [44] \\
\hline
\end{tabular}

POM: polyoxometalate. RT: room temperature. EPS: extracellular polymeric substances. HTC: hydrothermal carbonization. UV: ultraviolet. TVF: Taylor vortex flow. BM: ball milling. ${ }^{\text {a }}$ Values determined from XPS elemental analysis. ${ }^{b}$ Values determined from XRD analysis.

\section{Carbon Structures Derived from Biomass}

Biomass typically presents a carbon content between $45 \%$ and $50 \%$. The isolation of carbon from other chemical elements is accomplished by thermochemical treatments, such as pyrolysis, hydrothermal carbonization (HTC), or a combination of both processes. The materials obtained from biomass conversion present distinct properties that mainly rely on the starting carbon precursor and processing strategies [56,57].

Pyrolysis is the decomposition of biomass in temperatures typically between 350 and $1100{ }^{\circ} \mathrm{C}$ under inert atmosphere. Conventional pyrolysis is performed in a tubular furnace, where the heat generated by electricity is transferred to the biomass. The alternative microwave-assisted pyrolysis generates localized heat, being an energy efficient and timesaving method [58]. This method improves the surface area of materials. For example, hay-derived activated biochar produced by microwave pyrolysis showed a surface area $30 \%$ higher in comparison to conventional pyrolysis [59].

Starbon ${ }^{\circledR}$ is a patented technology that uses conventional pyrolysis to convert polysaccharides into carbonaceous mesoporous materials, commercially designated as Starbons [60]. Starch was the first polysaccharide used as a precursor for Starbons technology. The conventional preparation route comprises several sequential steps: (i) starch gelatinization, (ii) starch retrogradation, (iii) solvent exchange, (iv) drying, and (v) carbonization. For example, corn starch was gelatinized in heated distilled water and recrystallized by cooling down at $5{ }^{\circ} \mathrm{C}$. Water from the retrograded starch gel was removed by solvent exchange with ethanol and dried to prevent collapse of the structure. The resulting material was pyrolyzed between 150 and $700{ }^{\circ} \mathrm{C}$, after being treated with $p$-toluene sulfonic acid to catalyze the carbonization and keep the porous structure. The expanded starch showed a Brunauer-Emmett-Teller specific surface area $\left(S_{\mathrm{BET}}\right)$ of approximately $180 \mathrm{~m}^{2} \mathrm{~g}^{-1}$ and a narrow pore volume of $0.4-0.6 \mathrm{~cm}^{3} \mathrm{~g}^{-1}$. The hydrophobicity of these materials was controlled by the degree of carbonization, producing more hydrophilic materials at lower temperatures [61]. The application of Starbons technology to alginic acid kept the first four steps in agreement with the starch processing, but the alginic acid gel was dried with supercritical $\mathrm{CO}_{2}$ and pyrolyzed in a broader temperature range of $200-1000{ }^{\circ} \mathrm{C}$. The mesoporous materials showed a $\mathrm{S}_{\mathrm{BET}}$ of $200 \mathrm{~m}^{2} \mathrm{~g}^{-1}$, but the different pyrolysis temperatures did not influence the specific surface area. Nevertheless, the higher temperatures produced carbon materials with more graphitic domains, as demonstrated by an increment $\mathrm{C} / \mathrm{O}$ ratio from XPS and elemental analysis techniques [62].

HTC is a thermochemical conversion method alternative to pyrolysis, in which biomass is processed inside a sealed autoclave at mild conditions using water as solvent. The mild processing temperatures, typically between 120 and $280^{\circ} \mathrm{C}$, generate supercritical 
water that promotes the biomass conversion. HTC consumes less energy compared with pyrolysis, being more sustainable from an ecological point of view. In this context, the microwave-assisted HTC is an alternative way that saves even more time and energy. For example, spherical carbon particles with a carbon content $>90 \%$ were prepared by processing glucose only during $15 \mathrm{~min}$ by microwave-assisted HTC [63].

The HTC of carbohydrates involves complex chemical reactions, which can be divided into five general stages: (i) hydrolysis, (ii) dehydration, (iii) decarboxylation, (iv) polymerization, and (v) aromatization [57]. Figure 2 shows the proposed mechanism for the HTC of cellulose.

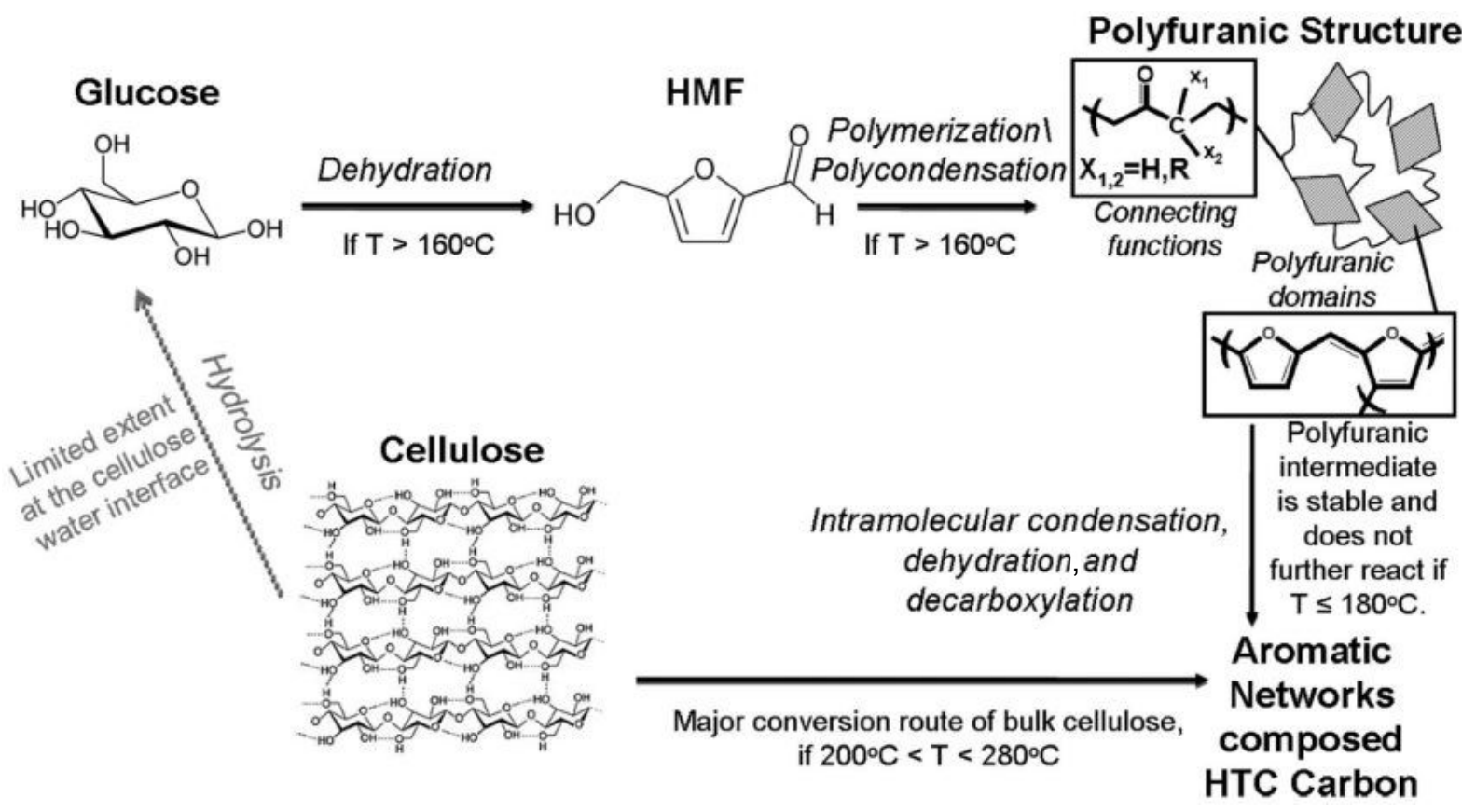

Figure 2. Proposed mechanism for HTC of cellulose. Reproduced with permission from Falco et al. Green Chem. 2011, 13, 3273 published by the Royal Society of Chemistry [64].

Titirici et al. [65] investigated the structure and morphology of materials processed by $\mathrm{HTC}$ at $180{ }^{\circ} \mathrm{C}$ during $24 \mathrm{~h}$ using different mono- and polysaccharides as carbon sources. Hexoses-containing compounds (glucose, maltose, sucrose, amylopectin, and starch) and hexose derivative 5-hydroxymethyl-furfural-1-aldehyde produced interconnected particles and agglomerated spheres. The hexoses dehydrate into hydroxymethyl furfural and condense to form carbonaceous materials with a similar structure and composition. The interconnected hexose-derived structures result from the good water solubility of hydroxymethyl furfural. On the other hand, xylose and furfural, a pentose-containing compound and a pentose derivative, respectively, produced well-dispersed spheres. Xylose dehydrates to form furfural, which has a limited water solubility, and polymerizes, forming carbon structures identical to the ones obtained from pure furfural. The materials obtained from mono- and polysaccharides were identical. For example, cellulose at the water/cellulose interface hydrolyzes to glucose, following the mechanism of hexoses, as shown in Figure 2. On the other hand, raw cellulose follows a reaction mechanism associated with pyrolysis yielding highly aromatic materials even at mild conditions, since high pressure destabilizes the cellulose structure. The same study compares the temperature of biomass decomposition by HTC and pyrolysis processes. Rye straw biomass submitted to HTC decomposed between 240 and $280{ }^{\circ} \mathrm{C}$, while during pyrolysis decomposition only started at $350{ }^{\circ} \mathrm{C}$. The lower temperature required for rye straw decomposition by HTC is attributed to the high pressure involved in the process. Another advantage of the HTC process is the possibility to control the chemical composition of carbonaceous materials such as furan-to-arene ratio [66]. 
The hydrothermal treatment introduces oxygen-containing groups to the carbon structures, typically producing materials with reduced electrical conductivity. The addition of GO to glucose, used as carbon source, before HTC increases the electrical conductivity of the hydrothermal species obtained [67]. In this context, the HTC followed by a pyrolysis step is an efficient strategy to improve the electrical conductivity, as demonstrated with the conversion of sugar cane into an electrically conductive aerogel. The aerogel conductivity increased from 0.4 to $1.3 \mathrm{~S} \mathrm{~cm}^{-1}$, with the increment of HTC time before pyrolysis [68]. Similarly, chitosan treated by HTC followed by pyrolysis produced carbon structures with high electrical conductivity, having the advantage of maintaining the nitrogen atoms available for further functionalization. Post-pyrolysis transforms the $\mathrm{sp}^{3}$ hybridized carbons into $\mathrm{sp}^{2}$ carbons, being a fundamental step to increase the graphitization of the hydrothermal carbons [69].

HTC produces carbonaceous materials with a very low surface area and undeveloped porosity. Zhong et al. [70] proposed a vapor-phase alternative HTC treatment to carbonize monosaccharides. Sucrose was treated in a glass vial placed inside an autoclave, while the gap between the autoclave and the vial was filled with water during $24 \mathrm{~h}$ at $200{ }^{\circ} \mathrm{C}$. This strategy produced spongelike mesoporous carbons, in opposition to the nonporous carbon material typically obtained by conventional HTC of sucrose. The combination of HTC followed by pyrolysis also creates porosity, reinforcing the benefits of using both thermochemical processes [71,72]. In this regard, the use of templates to shape the carbon materials during biomass conversion is a powerful method to tune the porosity and surface area.

The carbon nanostructures derived from biomass are sustainable and low-cost alternatives to graphene derivatives. HTC is an economical and eco-friendly technique since it uses mild temperatures, self-generated pressure, and water as solvent. Pyrolysis uses higher temperatures in comparison with HTC; however, it can still be considered a relatively economical technique. The combination of HTC and pyrolysis techniques may lower the energy consumption required for pyrolysis, making the process more economical and eco-friendlier. The porosity and mechanical and electrical properties of these graphitic structures can be modified by the processing conditions, tailoring their properties to become fillers of polymeric composite materials.

\section{Graphitic Materials Supported on Lamellar Structures}

Clay minerals are natural and abundant resources, adequate for the sustainable development of ecological materials. The porosity and functional groups present in natural or synthetic clays turn them into suitable platforms to adsorb diverse types of molecules [73,74], leading to a wide variety of uses, including hybrid materials for advanced applications [75]. Therefore, clays have been used as porous templates to produce nanostructured carbon materials. In this context, the use of clays can be done in two different approaches: as molds or templates that are removed after carbonization of a carbon precursor $[76,77]$ or, alternatively, as supports maintained after nanocomposite synthesis $[78,79]$.

Sepiolite is a natural hydrated magnesium silicate showing a microfibrous morphology that has been deeply investigated to prepare carbon nanomaterials and nanocomposites as either template or support. The structure of this clay mineral is organized in alternate $\mathrm{Mg}$-silicate blocks and intracrystalline nanopores aligned in the fiber direction. This structural organization, forming interior cavities (tunnels) and exterior channels, turns sepiolite into an attractive template [80]. Acrylonitrile was adsorbed into sepiolite pores, polymerized to obtain polyacrylonitrile, and thermally treated by pyrolysis at $750{ }^{\circ} \mathrm{C}$ under $\mathrm{N}_{2}$ flow. The resulting carbon-clay nanocomposites were electrically conductive, maintaining the silicate template, which was removed with acid treatments, and free carbon fibers with $1 \mu \mathrm{m}$ length and $20 \mathrm{~nm}$ diameter were obtained [73]. Carbon-sepiolite nanocomposites derived from cellulose were synthesized by HTC using sepiolite pretreated with hydrochloric acid. These acid treatments increase the amount of surface silanol groups 
(Si-OH) present at the clay surface due to the extraction of $\mathrm{Mg}^{2+}$ ions from its structure. The resulting carbon-sepiolite nanocomposites showed an increased adsorption capacity towards organic compounds, such as methylene blue and phenols, in comparison with pristine sepiolite [81]. However, these treatments could introduce deep alterations in the crystal order of the starting sepiolite generating silica-based materials [82-84]. Given that sepiolite interacts with diverse biopolymers through hydrogen bonding [81,85,86], according to $\mathrm{Wu}$ et al. [74] the increase in acid pretreatment that increased the silanol group density promotes the interactions with cellulose and, consequently, the carbon content in the final nanocomposites [77]. However, an alternative explanation should be considered, taking into account the significant increase in the specific surface area of the silicate-based materials produced by the acid treatments, which can promote the interaction with the polymers.

Graphene-like materials were also prepared using sucrose or gelatin supported on sepiolite clay. The carbon-clay bionanocomposites obtained after pyrolysis at $800^{\circ} \mathrm{C}$ under $\mathrm{N}_{2}$ atmosphere presented an electrical conductivity in the range of $0.01-1 \mathrm{~S} \mathrm{~cm}^{-1}$. The use of gelatin biopolymer as carbon precursor produced N-modified materials, being advantageous for further functionalization [78].

A 2D-layered silicate montmorillonite has also successfully been used as a porous template. Electrically conductive and porous caramel-clay nanocomposites were prepared from sucrose intercalated into montmorillonite in a melting process (i.e., through in situ formed caramel) [77]. In this way, the precursors in the absence of solvents were polymerized using microwave radiation and further pyrolyzed at $750{ }^{\circ} \mathrm{C}$ under $\mathrm{N}_{2}$ atmosphere [79]. Following this work, a water solution of caramel (commercial liquid caramel) was also used as a precursor. Caramel was impregnated into montmorillonite or sepiolite clays and thermally treated under the same pyrolysis conditions to obtain the graphene-like materials [79].

In contrast to 2D clay minerals, such as montmorillonite, sepiolite does not have swelling properties and the formation of intercalated compounds is not possible. In this case, caramel is presumed to fill the sepiolite pores and cover the external surface in agreement with $\mathrm{N}_{2}$ adsorption isotherms of the resulting nanocomposites [87]. The formation of graphitic material into porous silicate templates is represented in Figure 3. The graphitic material can be formed in the interior of the pores by an endogenic mechanism or at the silicate surface by an exogenic mechanism [88]. Al-pillared montmorillonite and glucose were treated by HTC followed by pyrolysis to synthesize another family of carbon-clay nanocomposites. The thermal treatments converted glucose into carbon clusters located in the montmorillonite layers and surface. Free carbon microspheres were also formed due to the HTC process. The montmorillonite pillaring strategy improved the $S_{\mathrm{BET}}$ from $27.1 \mathrm{~m}^{2} \mathrm{~g}^{-1}$ to $129.6 \mathrm{~m}^{2} \mathrm{~g}^{-1}$ due to an increase in montmorillonite layers separation. The introduction of carbon and its conversion resulted into nanocomposites with a $\mathrm{S}_{\mathrm{BET}}$ of $162.6 \mathrm{~m}^{2} \mathrm{~g}^{-1}$, a pore volume inferior to $0.1 \mathrm{~cm}^{3} \mathrm{~g}^{-1}$, and an average pore size of $4.3 \mathrm{~nm}$ [89]. These $\mathrm{S}_{\mathrm{BET}}$ and pore volume are lower compared with the values obtained for mesoporous carbons prepared by the removal of a laponite clay template [90].

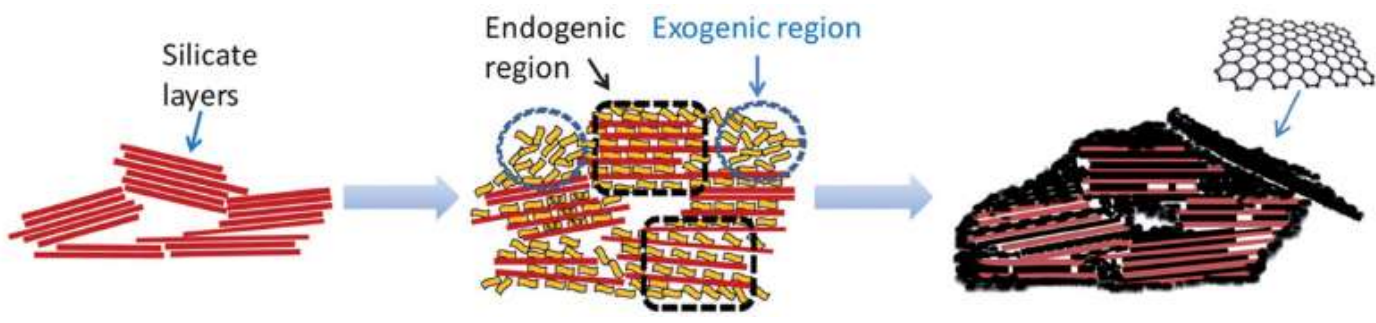

Figure 3. Schematic representation of graphene-like materials formed inside sepiolite pores (endogenic regions) and epitaxially grown on the sepiolite surface (exogenic regions). Reproduced with permission from Ruiz-García et al., J. Mater. Chem. A 2017, 2009, published by the Royal Society of Chemistry [88]. 
The removal of a clay template is advantageous to produce carbon nanomaterials with a large surface area. However, this strategy may be time-consuming and nonsustainable due to the use of toxic chemicals [77,90]. On the other hand, the maintenance of the clay template results in carbon-clay hybrid nanocomposites. The incorporation of these materials as fillers into insulating polymer matrices to produce composites can make them electrically conductive and improve their barrier and mechanical properties. The template maintenance is also advantageous for further material functionalization due to the presence of clay functional groups $[87,88,91]$. Nevertheless, despite the advantages of this strategy, it produces materials with inferior textural properties compared with the clay template removal $[89,90]$.

MXenes are a large family of transition metal carbides, carbonitrides, and nitrides showing a general formula, $M_{n+1} X_{n} T_{X}$, where $M$ is an early transition metal (e.g., Ti), $X$ is carbon and/or nitrogen, and $\mathrm{T}_{\mathrm{x}}$ represents termination groups (e.g., $\mathrm{OH}$ ) [92]. Interestingly, they exhibit colloidal and surface properties in close relation to clay minerals but show useful additional properties, such as metallic electrical conductivity. These materials are excellent candidates to form carbon-based nanocomposites and, for instance, porous carbon nanospheres generated by pyrolysis of chitosan could be assembled to $\mathrm{Ti}_{3} \mathrm{C}_{2} \mathrm{~T}_{\mathrm{x}} \mathrm{MXene}$, as recently reported [93]. The resulting carbon-nanostructured materials (Figure 4) provide an elevated specific surface area $\left(>1800 \mathrm{~m}^{2} \mathrm{~g}^{-1}\right)$ and improved adsorption properties tested in dye adsorption from aqueous solutions. For instance, the adsorption capacity of crystal violet is close to $2750 \mathrm{mg} \mathrm{g}^{-1}$, which appears to be the highest adsorbed amount of dye per mass unit never reported for carbon-based materials [93].



Figure 4. Schematic representation of the assembly of hydrothermal carbon spheres (HCS) from chitosan (CS) and $\mathrm{Ti}_{3} \mathrm{C}_{2} \mathrm{~T}_{\mathrm{x}}$ MXene. Reproduced with permission from Wu et al., Chem. Eng. J. 2021, 426, 130776, published by Elsevier [93].

\section{Polymer Composites Containing rGO}

Carbon nanostructures are used to reinforce the mechanical, electrical, thermal, and optical properties of polymeric matrices. Therefore, biocomposites containing carbonaceous materials have application in many distinct fields. To the best of the author's knowledge, among the carbon nanostructures reviewed in this paper, only rGO was applied to prepare polymer-based composites. However, the carbons derived from biomass and the claysupported carbons have potential for the development of polymer-based composites. One advantage is the selection of the carbon precursor according to the applications. For example, a carbon precursor containing N- or S- functional groups may not only reinforce the composite through the establishment of interactions with the polymer but also improve their performance on the application. Similarly, the electrical conductivity and porosity of 
the carbon nanostructures can be tailored by an appropriate selection of the methodology. Therefore, the alternative green carbon nanostructures are promising materials for the development of polymer-based composites.

Table 2 presents the polymer composite materials prepared using the rGO reduced by the green methodologies listed in Table 1. The applications found for these materials were corrosion protection [29,49,50], gas diffusion barriers [47], sensing [21], supercapacitors [35], environmental remediation [39], and food packaging [9,94]. Recently, we revised the use of graphene derivatives in biopolymer composite nanostructures for food packaging applications, which is an example of application where these green carbon nanostructures can be employed [95].

Table 2. Applications of polymer-based composites prepared using the green carbon nanostructures previously reviewed.

\begin{tabular}{|c|c|c|c|c|}
\hline Application & Carbon Nanostructure & Polymer Composite & Results & Ref. \\
\hline $\begin{array}{l}\text { Corrosion } \\
\text { protection }\end{array}$ & rGO (Urtica dioica leaf) & $\begin{array}{l}\text { Polyurethane /rGO }(0.15 \mathrm{wt} \%) \\
\text { coatings (tested on mild steel) }\end{array}$ & $\begin{array}{c}\text { Resistance against accelerated } \\
\text { weathering condition; improved UV } \\
\text { shielding and corrosion protection } \\
\text { efficiency. }\end{array}$ & [29] \\
\hline $\begin{array}{l}\text { Corrosion } \\
\text { protection }\end{array}$ & $\begin{array}{l}\text { rGO (Peganum harmala } \\
\text { seed) }\end{array}$ & $\begin{array}{c}\text { Epoxy resin/rGO-Zn }(0.15 \\
\text { wt } \%) \text { coatings (tested on steel) }\end{array}$ & $\begin{array}{l}\text { Dual active and barrier corrosion } \\
\text { protection. }\end{array}$ & [49] \\
\hline $\begin{array}{l}\text { Corrosion } \\
\text { protection }\end{array}$ & $\begin{array}{c}\text { rGO (Peganum harmala } \\
\text { seed) }\end{array}$ & $\begin{array}{c}\text { Epoxy ester resin } / \mathrm{rGO}-\mathrm{Zn} \\
(0.15 \mathrm{wt} \%) \text { coating (tested on } \\
\text { steel) }\end{array}$ & $\begin{array}{c}\text { Improved tensile strength }(78 \%), \\
\text { Young's modulus }(102 \%) \text { and fracture } \\
\text { energy }(83 \%) ; \text { improved thermal } \\
\text { stability }(62 \%) .\end{array}$ & {$[50]$} \\
\hline $\begin{array}{l}\text { Gas diffusion } \\
\text { barrier }\end{array}$ & rGO (elemental sulfur) & $\begin{array}{l}\text { Polyimide / rGO }(0.5-5 w \mathrm{t} \%) \\
\text { films }\end{array}$ & $\begin{array}{l}\text { Improved tensile strength and } \\
\text { Young's modulus; } 95 \% \text { reduction of } \\
\text { oxygen permeability. }\end{array}$ & [47] \\
\hline Sensing & $\begin{array}{c}\text { rGO (Bougainvillea glabra } \\
\text { flower) }\end{array}$ & $\begin{array}{l}\text { Nafion/rGO solution } \\
\text { drop-casted on a carbon } \\
\text { working electrode }\end{array}$ & $\begin{array}{c}\text { Sensor electrode used for } \mathrm{Pb}^{2+} \\
\text { detection; improved sensitivity and } \\
\text { ultralow limit of detection. }\end{array}$ & [21] \\
\hline Supercapacitors & rGO (eucalyptus bark) & $\begin{array}{c}\text { Nafion } / \text { rGO solution } \\
\text { drop-casted on a glassy carbon } \\
\text { electrode }\end{array}$ & $\begin{array}{l}\text { High specific capacitance }\left(239 \mathrm{~F} \mathrm{~g}^{-1}\right) \\
\text { and high energy density }\left(71 \mathrm{~W} \mathrm{~h} \mathrm{~kg}^{-1}\right) \\
\text { at a current density of } 2 \mathrm{~A} \mathrm{~g}^{-1} \text {. }\end{array}$ & [35] \\
\hline $\begin{array}{l}\text { Environmental } \\
\text { remediation }\end{array}$ & $\begin{array}{c}\text { rGO } \\
\text { (Pseudoalteromonas sp.) }\end{array}$ & $\begin{array}{l}\text { Sodium alginate } / \mathrm{rGO} \text { solution } \\
\text { dripped into } \mathrm{CaCl}_{2} \text { solution to } \\
\text { obtain spheres }\end{array}$ & $\begin{array}{l}\text { MB and CR dye adsorption from } \\
\text { water. Reusable absorbent with } \\
\text { adsorption efficiency of the MB and } \\
\text { CR } 77.91 \% \text { and } 68.27 \% \text { after } 4 \\
\text { adsorption-desorption cycles. }\end{array}$ & [39] \\
\hline Food packaging & rGO (HTC/caffeic acid) & Chitosan/rGO (50\%) film & $\begin{array}{l}\text { Electrically conductive film to sterilize } \\
\text { food by in-pack PEF; electrical } \\
\text { conductivity of } 0.7 \mathrm{~S} \mathrm{~m}^{-1} \text { and } \\
2.1 \times 10^{-5} \mathrm{~S} \mathrm{~m}^{-1} \text { in-plane and } \\
\text { through-plane, respectively. }\end{array}$ & [9] \\
\hline Food packaging & rGO (HTC/ZnO) & $\begin{array}{l}\text { Alginate/sepiolite/ZnO-rGO } \\
(50 \%)\end{array}$ & $\begin{array}{l}\text { Antimicrobial and electrically } \\
\text { conductive film for food packaging. } \\
\text { E. coli and S. } \\
\text { Inhibition of aureus growth; electrical } \\
\text { conductivity of } 0.1 \mathrm{~S} \mathrm{~m}^{-1} \text { and } \\
7.5 \times 10^{-5} \mathrm{~S} \mathrm{~m}^{-1} \text { in-plane and } \\
\text { through-plane, respectively. }\end{array}$ & [94] \\
\hline Not mentioned & $\mathrm{rGO}(\mathrm{BM} / \mathrm{Zn})$ & $\begin{array}{l}\text { Epoxy resin/rGO }(0.1-0.3 \%) \\
\text { composites }\end{array}$ & $\begin{array}{c}\text { Improvement of thermomechanical } \\
\text { properties. }\end{array}$ & [44] \\
\hline
\end{tabular}

rGO: reduced graphene oxide. UV: ultraviolet. MB: methylene blue. CR: Congo red. HTC: hydrothermal carbonization. PEF: pulsed electric field. BM: ball milling.

The mechanical reinforcement promoted by the incorporation of a carbon nanostructure into a polymer matrix is a general effect with interest in most of areas $[9,44,47,50]$. The synthesis methods and precursors of carbon nanostructures should be carefully selected 
since they can influence the preparation of composites. In some cases, the use of green chemical reductants was an advantage in the preparation of polymer composites. For example, the Peganum harmala seed extract used to prepare rGO had a dual role as reducing agent and corrosion inhibitor. Therefore, the coatings containing rGO prepared with this plant extract acted not only as a barrier but also as an active corrosion coating [49]. Similarly, the simultaneous reduction and modification of GO with elemental sulfur produced S-rGO with good adsorption capacities towards $\mathrm{Hg}$ (II) due to the high affinity between sulfur and metallic adsorbates. In addition, S-rGO showed good interfacial interactions with the polystyrene polymer, which improved the dispersibility of the filler and the mechanical properties of the resulting composites [47]. Additionally, the presence of clays used to support carbon nanomaterials can improve their dispersion into the polymer matrix [96].

\section{Conclusions and Future Perspectives}

Green carbon structures prepared using low-cost, eco-friendly, and sustainable methodologies may be additives of interest to modify the mechanical, electrical, and barrier properties of polymers. The use of natural carbon precursors, green reactants, and sustainable methodologies allows the development of versatile composites for a variety of applications in a wide number of fields, including biological and food areas. The use of carbon nanomaterials derived from biomass, such as hydrothermal carbons or carbons supported on clays, in the fabrication of polymer composites has a high potential of exploration since they were not used for this purpose yet. In addition, natural biopolymers can be used as a composite's matrices to ensure the final material sustainability. These materials are expected to present comparable properties with the polymer-based composites using rGO as a filler, with the advantage of being cost-effective, safe, and environmentally sustainable.

Author Contributions: A.B.: investigation, writing—original draft preparation, review, and editing. C.N., E.R.-H. and P.F.: supervision, writing-review, and funding acquisition. All authors have read and agreed to the published version of the manuscript.

Funding: This work was developed within the scope of the projects CICECO-Aveiro Institute of Materials, UIDB/50011/2020 and UIDP/50011/2020, and BIOFOODPACK (M-ERA-NET2/0021/2016). A.B. and P.F. are thankful to FCT for the grant SFRH/BD/148856/2019 and the Investigator FCT (IF/00300/2015), respectively. CN is grateful for Portuguese national funds (OE), through FCT, IP, within the scope of the framework contract foreseen in numbers 4, 5, and 6 of Article 23 of DecreeLaw 57/2016 of 29 August, changed by Law 57/2017 of 19 July. E.R.-H. gratefully acknowledges the financial support from AEI (Spain) and FEDER (EU) funds (projects MAT2015-71117-R and PID2019-105479RB-I00, respectively).

Conflicts of Interest: The authors declare no conflict of interest.

\section{References}

1. Bianco, A.; Cheng, H.M.; Enoki, T.; Gogotsi, Y.; Hurt, R.H.; Koratkar, N.; Kyotani, T.; Monthioux, M.; Park, C.R.; Tascon, J.M.D.; et al. All in the graphene family-A recommended nomenclature for two-dimensional carbon materials. Carbon 2013, 65, 1-6. [CrossRef]

2. Novoselov, K.S.; Geim, A.K.; Morozov, S.V.; Jiang, D.; Zhang, Y.; Dubonos, S.V.; Grigorieva, I.V.; Firsov, A.A. Electric Field Effect in Atomically Thin Carbon Films. Science 2004, 306, 666-669. [CrossRef] [PubMed]

3. Wang, X.-Y.; Narita, A.; Müllen, K. Precision synthesis versus bulk-scale fabrication of graphenes. Nat. Rev. Chem. 2018, 2, 0100. [CrossRef]

4. Lin, L.; Deng, B.; Sun, J.; Peng, H.; Liu, Z. Bridging the Gap between Reality and Ideal in Chemical Vapor Deposition Growth of Graphene. Chem. Rev. 2018, 118, 9281-9343. [CrossRef]

5. Stoller, M.D.; Park, S.; Yanwu, Z.; An, J.; Ruoff, R.S. Graphene-Based ultracapacitors. Nano Lett. 2008, 8, 3498-3502. [CrossRef]

6. Wick, P.; Louw-Gaume, A.E.; Kucki, M.; Krug, H.F.; Kostarelos, K.; Fadeel, B.; Dawson, K.A.; Salvati, A.; Vázquez, E.; Ballerini, L.; et al. Classification Framework for Graphene-Based Materials; Wiley-VCH Verlag: New York, NY, USA, 2014; Volume 53, pp. 7714-7718.

7. Shen, J.; Hu, Y.; Li, C.; Qin, C.; Ye, M. Synthesis of amphiphilic graphene nanoplatelets. Small 2009, 5, 82-85. [CrossRef]

8. Loeffen, A.; Cree, D.E.; Sabzevari, M.; Wilson, L.D. Effect of Graphene Oxide as a Reinforcement in a Bio-Epoxy Composite. J. Compos. Sci. 2021, 5, 91. [CrossRef] 
9. $\quad$ Barra, A.; Ferreira, N.M.N.M.; Martins, M.A.M.A.; Lazar, O.; Pantazi, A.; Jderu, A.A.A.A.; Neumayer, S.M.S.M.; Rodriguez, B.J.B.J.; Enăchescu, M.; Ferreira, P.; et al. Eco-friendly preparation of electrically conductive chitosan-reduced graphene oxide flexible bionanocomposites for food packaging and biological applications. Compos. Sci. Technol. 2019, 173, 53-60. [CrossRef]

10. Eatemadi, A.; Daraee, H.; Karimkhanloo, H.; Kouhi, M.; Zarghami, N. Carbon nanotubes: Properties, synthesis, purification, and medical applications. Nanoscale Res. Lett. 2014, 9, 393. [CrossRef]

11. Chua, C.K.; Pumera, M. Chemical reduction of graphene oxide: A synthetic chemistry viewpoint. Chem. Soc. Rev. 2014, 43, 291-312. [CrossRef]

12. Marcano, D.C.; Kosynkin, D.V.; Berlin, J.M.; Sinitskii, A.; Sun, Z.; Slesarev, A.; Alemany, L.B.; Lu, W.; Tour, J.M. Improved synthesis of graphene oxide. ACS Nano 2010, 4, 4806-4814. [CrossRef]

13. Xu, Y.; Bai, H.; Lu, G.; Li, C.; Shi, G. Flexible graphene films via the filtration of water-soluble noncovalent functionalized graphene sheets. J. Am. Chem. Soc. 2008, 130, 5856-5857. [CrossRef]

14. Coros, M.; Pogacean, F.; Turza, A.; Dan, M.; Berghian-Grosan, C.; Pana, I.O.; Pruneanu, S. Green synthesis, characterization and potential application of reduced graphene oxide. Phys. E Low-Dimens. Syst. Nanostruct. 2020, 119, 113971. [CrossRef]

15. Stankovich, S.; Dikin, D.A.; Piner, R.D.; Kohlhaas, K.A.; Kleinhammes, A.; Jia, Y.; Wu, Y.; Nguyen, S.B.T.; Ruoff, R.S. Synthesis of graphene-based nanosheets via chemical reduction of exfoliated graphite oxide. Carbon 2007, 45, 1558-1565. [CrossRef]

16. De Silva, K.K.H.; Huang, H.H.; Yoshimura, M. Progress of reduction of graphene oxide by ascorbic acid. Appl. Surf. Sci. 2018, 447, 338-346. [CrossRef]

17. Eigler, S.; Dotzer, C.; Hirsch, A. Visualization of defect densities in reduced graphene oxide. Carbon 2012, 50, 3666-3673. [CrossRef]

18. Fujimoto, A.; Yamada, Y.; Koinuma, M.; Sato, S. Origins of sp3C peaks in C1s X-ray Photoelectron Spectra of Carbon Materials. Anal. Chem. 2016, 88, 6110-6114. [CrossRef]

19. Hortigüela, M.J.; Machado, D.; Bdikin, I.; Neto, V.; Otero-Irurueta, G. Chemical changes of graphene oxide thin films induced by thermal treatment under vacuum conditions. Coatings 2020, 10, 113. [CrossRef]

20. Barra, A.; Lazăr, O.; Pantazi, A.; Hortigüela, M.J.; Otero-Irurueta, G.; Enăchescu, M.; Ruiz-Hitzky, E.; Nunes, C.; Ferreira, P. Joining Caffeic Acid and Hydrothermal Treatment to Produce Environmentally Benign Highly Reduced Graphene Oxide. Nanomaterials 2021, 11, 732. [CrossRef]

21. Mahendran, G.B.; Ramalingam, S.J.; Rayappan, J.B.B.; Kesavan, S.; Periathambi, T.; Nesakumar, N. Green preparation of reduced graphene oxide by Bougainvillea glabra flower extract and sensing application. J. Mater. Sci. Mater. Electron. 2020, 31, 14345-14356. [CrossRef]

22. Zhang, T.; Zhu, G.Y.; Yu, C.H.; Xie, Y.; Xia, M.Y.; Lu, B.Y.; Fei, X.; Peng, Q. The UV absorption of graphene oxide is size-dependent: Possible calibration pitfalls. Microchim. Acta 2019, 186, 207. [CrossRef] [PubMed]

23. Li, D.; Müller, M.B.; Gilje, S.; Kaner, R.B.; Wallace, G.G. Processable aqueous dispersions of graphene nanosheets. Nat. Nanotechnol. 2008, 3, 101-105. [CrossRef] [PubMed]

24. Farivar, F.; Lay, P.; Hassan, K.; Thanh, T.; Tran, D.N.H.; Pollard, A.J.; Losic, D. Unlocking thermogravimetric analysis (TGA) in the fight against "Fake graphene" materials. Carbon 2021, 179, 505-513. [CrossRef]

25. Narayanan, K.B.; Kim, H.D.; Han, S.S. Biocompatibility and hemocompatibility of hydrothermally derived reduced graphene oxide using soluble starch as a reducing agent. Colloids Surf. B Biointerfaces 2020, 185, 110579. [CrossRef]

26. Longo, A.; Palomba, M.; Carotenuto, G. Green Solid-State Chemical Reduction of Graphene Oxide Supported on a Paper Substrate. Coatings 2020, 10, 693. [CrossRef]

27. El-Hallag, I.S.; El-Nahass, M.N.; Youssry, S.M.; Kumar, R.; Abdel-Galeil, M.M.; Matsuda, A. Facile in-situ simultaneous electrochemical reduction and deposition of reduced graphene oxide embedded palladium nanoparticles as high performance electrode materials for supercapacitor with excellent rate capability. Electrochim. Acta 2019, 314, 124-134. [CrossRef]

28. Mascarenhas, F.C.; Sykam, N.; Selvakumar, M.; Mahesha, M.G. Green reduction of graphene oxide using Indian gooseberry (amla) extract for gas sensing applications. J. Environ. Chem. Eng. 2020, 8, 103712. [CrossRef]

29. Mahmudzadeh, M.; Yari, H.; Ramezanzadeh, B.; Mahdavian, M. Urtica dioica extract as a facile green reductant of graphene oxide for UV resistant and corrosion protective polyurethane coating fabrication. J. Ind. Eng. Chem. 2019, 78, 125-136. [CrossRef]

30. Liu, Y.; Li, Y.; Yang, Y.; Wen, Y.; Wang, M. Reduction of graphene oxide by thiourea. J. Nanosci. Nanotechnol. 2011, 11, 10082-10086. [CrossRef]

31. Amarnath, C.A.; Hong, C.E.; Kim, N.H.; Ku, B.C.; Kuila, T.; Lee, J.H. Efficient synthesis of graphene sheets using pyrrole as a reducing agent. Carbon 2011, 49, 3497-3502. [CrossRef]

32. Wang, J.; Fei, G.; Pan, Y.; Zhang, K.; Hao, S.; Zheng, Z.; Xia, H. Simultaneous reduction and surface functionalization of graphene oxide by cystamine dihydrochloride for rubber composites. Compos. Part A Appl. Sci. Manuf. 2019, 122, 18-26. [CrossRef]

33. Zhang, H.; Kuila, T.; Kim, N.H.; Yu, D.S.; Lee, J.H. Simultaneous reduction, exfoliation, and nitrogen doping of graphene oxide via a hydrothermal reaction for energy storage electrode materials. Carbon 2014, 69, 66-78. [CrossRef]

34. Zhang, J.; Yang, H.; Shen, G.; Cheng, P.; Zhang, J.; Guo, S. Reduction of graphene oxide via L-ascorbic acid. Chem. Commun. 2010, 46, 1112-1114. [CrossRef] [PubMed]

35. Manchala, S.; Tandava, V.S.R.K.; Jampaiah, D.; Bhargava, S.K.; Shanker, V. Novel and Highly Efficient Strategy for the Green Synthesis of Soluble Graphene by Aqueous Polyphenol Extracts of Eucalyptus Bark and Its Applications in High-Performance Supercapacitors. ACS Sustain. Chem. Eng. 2019, 7, 11612-11620. [CrossRef] 
36. Kumar, P.; Harish; Andersson, G.; Subhedar, K.M.; Dhami, H.S.; Gupta, G.; Mukhopadhyay, A.K.; Joshi, R.P. Utilization of green reductant Thuja Orientalis for reduction of GO to RGO. Ceram. Int. 2021, 47, 14862-14878. [CrossRef]

37. Kindalkar, V.S.; Kumara, K.; Bhat, S.; Dharmaprakash, S.M. An eco-friendly approach for the reduction of graphene oxide using Syzygium samarangense fruit extract. Mater. Chem. Phys. 2021, 261, 124224. [CrossRef]

38. Kalathil, S.; Katuri, K.P.; Alazmi, A.S.; Pedireddy, S.; Kornienko, N.; Costa, P.M.F.J.; Saikaly, P.E. Bioinspired Synthesis of Reduced Graphene Oxide-Wrapped Geobacter sulfurreducens as a Hybrid Electrocatalyst for Efficient Oxygen Evolution Reaction. Chem. Mater. 2019, 31, 3686-3693. [CrossRef]

39. Xu, B.; Cheng, S.; Han, M.; Li, Q.; Chen, W.; Zhou, W. The characteristic and performance of reduced graphene oxide by marine bacterium Pseudoalteromonas sp. CF10-13. Ceram. Int. 2020, 46, 21699-21706. [CrossRef]

40. Wang, H.; Huang, W.; Huang, S.; Xia, L.; Liu, X.; Li, Y.; Song, S.; Yang, L. A Green Method toward Graphene Oxide Reduction by Extracellular Polymeric Substances Assisted with NH4+. Arab. J. Sci. Eng. 2021, 46, 485-494. [CrossRef]

41. Dong, S.; Wang, Z.; Wang, J.; Asif, M.; Yao, Y.; Xiao, F.; Liu, H. Sulfate-reducing bacteria respiration approach to fabricating flexible N,S-reduced graphene oxide thin film electrode for in situ cancer biomarker detection. J. Electroanal. Chem. 2020, 859, 113867. [CrossRef]

42. Alves, Z.; Nunes, C.; Ferreira, P. Unravelling the Role of Synthesis Conditions on the Structure of Zinc Oxide-Reduced Graphene Oxide Nanofillers. Nanomaterials 2021, 11, 2149. [CrossRef]

43. Nam, K.H.; Jung Kim, U.; Hee Jeon, M.; Lee, T.R.; Yu, J.; You, N.H.; Kim, Y.K.; Won Suk, J.; Ku, B.C. Green, fast, and scalable production of reduced graphene oxide via Taylor vortex flow. Chem. Eng. J. 2020, 391, 123482. [CrossRef]

44. Tiwari, S.K.; Nimbalkar, A.S.; Hong, C.K.; Ha, S.K. A Green Route for Quick and Kilogram Production of Reduced Graphene Oxide and Their Applications at Low Loadings in Epoxy Resins. ChemistrySelect 2019, 4, 1266-1274. [CrossRef]

45. Thiyagarajulu, N.; Arumugam, S.; Narayanan, A.L.; Mathivanan, T.; Renuka, R.R. Green synthesis of reduced graphene nanosheets using leaf extract of tridax procumbens and its potential in vitro biological activities. Biointerface Res. Appl. Chem. 2020, 11, 9975-9984. [CrossRef]

46. Qi, J.; Zhang, S.; Xie, C.; Liu, Q.; Yang, S. Fabrication of Erythrina senegalensis leaf extract mediated reduced graphene oxide for cardiac repair applications in the nursing care. Inorg. Nano-Metal Chem. 2021, 51, 143-149. [CrossRef]

47. Nam, K.H.; Kim, K.; Kim, S.G.; Lee, H.S.; Jung, H.; Yu, J.; Jang, S.G.; Ku, B.C.; Moon, B.; You, N.H. Sustainable production of reduced graphene oxide using elemental sulfur for multifunctional composites. Compos. Part B Eng. 2019, 176, 107236. [CrossRef]

48. Debiemme-Chouvy, C.; Thomas, B.; Lucas, I.T.; Maï Tran, T.T.; Heintz, J.M.; Veillère, A.; Silvain, J.F. Facile and Green Reduction of Graphene Oxide by a Reduced Polyoxometalate and Formation of a Nanohybrid. Chempluschem 2017, 82, 186-189. [CrossRef]

49. Mohammadkhani, R.; Ramezanzadeh, M.; Akbarzadeh, S.; Bahlakeh, G.; Ramezanzadeh, B. Graphene oxide nanoplatforms reduction by green plant-sourced organic compounds for construction of an active anti-corrosion coating; experimental/electronicscale DFT-D modeling studies. Chem. Eng. J. 2020, 397, 125433. [CrossRef]

50. Ramezanzadeh, M.; Bahlakeh, G.; Ramezanzadeh, B. Green synthesis of reduced graphene oxide nanosheets decorated with zinccentered metal-organic film for epoxy-ester composite coating reinforcement: DFT-D modeling and experimental explorations. $J$. Taiwan Inst. Chem. Eng. 2020, 114, 311-330. [CrossRef]

51. Ansari, M.Z.; Johari, R.; Siddiqi, W.A. Novel and green synthesis of chemically reduced graphene sheets using Phyllanthus emblica (Indian Gooseberry) and its photovoltaic activity. Mater. Res. Express 2019, 6, 055027. [CrossRef]

52. Hashmi, A.; Singh, A.K.; Khan, A.A.P.; Asiri, A.M. Novel and Green Reduction of Graphene Oxide by Capsicum Annuum: Its Photo Catalytic Activity. J. Nat. Fibers 2020, 1-16. [CrossRef]

53. Fatima, F.; Singh, H.R.; Jha, S.K. Assessment of antioxidant and cytotoxicity activities against A-549 lung cancer cell line by synthesized reduced graphene oxide nanoparticles mediated by Camellia sinensis. 3 Biotech 2021, 11, 494. [CrossRef]

54. Xu, Q.; Lin, X.; Gan, L.; Owens, G.; Chen, Z. Green reduction of graphene oxide using Bacillus sphaericus. J. Colloid Interface Sci. 2022, 605, 881-887. [CrossRef]

55. Dominic, R.M.; Punniyakotti, P.; Balan, B.; Angaiah, S. Green synthesis of reduced graphene oxide using Plectranthus amboinicus leaf extract and its supercapacitive performance. Bull. Mater. Sci. 2021, 45, 2. [CrossRef]

56. Titirici, M.M.; White, R.J.; Brun, N.; Budarin, V.L.; Su, D.S.; Del Monte, F.; Clark, J.H.; MacLachlan, M.J. Sustainable carbon materials. Chem. Soc. Rev. 2015, 44, 250-290. [CrossRef] [PubMed]

57. Deng, J.; Li, M.; Wang, Y. Biomass-derived carbon: Synthesis and applications in energy storage and conversion. Green Chem. 2016, 18, 4824-4854. [CrossRef]

58. Foong, S.Y.; Liew, R.K.; Yang, Y.; Cheng, Y.W.; Yek, P.N.Y.; Wan Mahari, W.A.; Lee, X.Y.; Han, C.S.; Vo, D.V.N.; Van Le, Q.; et al. Valorization of biomass waste to engineered activated biochar by microwave pyrolysis: Progress, challenges, and future directions. Chem. Eng. J. 2020, 389, 124401. [CrossRef]

59. Kazmierczak-Razna, J.; Nowicki, P.; Wiśniewska, M.; Nosal-Wiercińska, A.; Pietrzak, R. Thermal and physicochemical properties of phosphorus-containing activated carbons obtained from biomass. J. Taiwan Inst. Chem. Eng. 2017, 80, 1006-1013. [CrossRef]

60. Budarin, V.L.; Clark, J.H.; Luque, R.; Macquarrie, D.J.; Milkowski, K.; White, R.J. Carbonaceous Materials. U.S. Patent 8790548B2, 29 July 2014.

61. Budarin, V.; Clark, J.H.; Hardy, J.J.E.; Luque, R.; Milkowski, K.; Tavener, S.J.; Wilson, A.J. Starbons: New Starch-Derived Mesoporous Carbonaceous Materials with Tunable Properties. Angew. Chem. Int. Ed. 2006, 45, 3782-3786. [CrossRef] 
62. White, R.J.; Antonio, C.; Budarin, V.L.; Bergström, E.; Thomas-Oates, J.; Clark, J.H. Polysaccharide-derived carbons for polar analyte separations. Adv. Funct. Mater. 2010, 20, 1834-1841. [CrossRef]

63. Jung, A.; Han, S.; Kim, T.; Cho, W.J.; Lee, K. Synthesis of high carbon content microspheres using 2-step microwave carbonization, and the influence of nitrogen doping on catalytic activity. Carbon N. Y. 2013, 60, 307-316. [CrossRef]

64. Falco, C.; Baccile, N.; Titirici, M.-M. Morphological and structural differences between glucose, cellulose and lignocellulosic biomass derived hydrothermal carbons. Green Chem. 2011, 13, 3273. [CrossRef]

65. Titirici, M.M.; Antonietti, M.; Baccile, N. Hydrothermal carbon from biomass: A comparison of the local structure from poly- to monosaccharides and pentoses/hexoses. Green Chem. 2008, 10, 1204-1212. [CrossRef]

66. Falco, C.; Caballero, F.P.; Babonneau, F.; Gervais, C.; Laurent, G.; Titirici, M.-M.; Baccile, N. Hydrothermal Carbon from Biomass: Structural Differences between Hydrothermal and Pyrolyzed Carbons via 13C Solid State NMR. Langmuir 2011, $27,14460-14471$. [CrossRef]

67. Krishnan, D.; Raidongia, K.; Shao, J.; Huang, J. Graphene oxide assisted hydrothermal carbonization of carbon hydrates. ACS Nano 2014, 8, 449-457. [CrossRef]

68. Li, Y.Q.; Samad, Y.A.; Polychronopoulou, K.; Liao, K. Lightweight and Highly Conductive Aerogel-like Carbon from Sugarcane with Superior Mechanical and EMI Shielding Properties. ACS Sustain. Chem. Eng. 2015, 3, 1419-1427. [CrossRef]

69. Zhao, L.; Baccile, N.; Gross, S.; Zhang, Y.; Wei, W.; Sun, Y.; Antonietti, M.; Titirici, M.M. Sustainable nitrogen-doped carbonaceous materials from biomass derivatives. Carbon 2010, 48, 3778-3787. [CrossRef]

70. Zhong, R.; Liao, Y.; Shu, R.; Ma, L.; Sels, B.F. Vapor-phase assisted hydrothermal carbon from sucrose and its application in acid catalysis. Green Chem. 2018, 20, 1345-1353. [CrossRef]

71. Yu, L.; Falco, C.; Weber, J.; White, R.J.; Howe, J.Y.; Titirici, M.M. Carbohydrate-derived hydrothermal carbons: A thorough characterization study. Langmuir 2012, 28, 12373-12383. [CrossRef]

72. Olszewski, M.P.; Nicolae, S.A.; Arauzo, P.J.; Titirici, M.; Kruse, A. Wet and dry? Influence of hydrothermal carbonization on the pyrolysis of spent grains. J. Clean. Prod. 2020, 260, 121101. [CrossRef]

73. Ruiz-Hitzky, E.; Aranda, P.; Serratosa, J.M. Clay-organic Interactions: Organoclay Complexes and Polymer-clay Nanocomposite In Handbook of Layered Materials; Aucherbach, S., Carrado, K.A., Dutta, P., Eds.; Taylor \& Francis: New York, NY, USA, $2004 ;$ p. 19.

74. Bergaya, F.; Theng, B.K.G.; Lagaly, G. Handbook of Clay Science, 1st ed.; Elsevier Science: Amsterdam, The Netherlands, 2006; ISBN 9780080441832.

75. Faustini, M.; Nicole, L.; Ruiz-Hitzky, E.; Sanchez, C. History of Organic-Inorganic Hybrid Materials: Prehistory, Art, Science, and Advanced Applications. Adv. Funct. Mater. 2018, 28, 1704158. [CrossRef]

76. Kyotani, T.; Sonobe, N.; Tomita, A. Formation of highly orientated graphite from polyacrylonitrile by using a two-dimensional space between montmorillonite lamellae. Nature 1988, 331, 331-333. [CrossRef]

77. Fernández-Saavedra, R.; Aranda, P.; Ruiz-Hitzky, E. Templated synthesis of carbon nanofibers from polyacrylonitrile using sepiolite. Adv. Funct. Mater. 2004, 14, 77-82. [CrossRef]

78. Ruiz-Hitzky, E.; Darder, M.; Fernandes, F.M.; Zatile, E.; Palomares, F.J.; Aranda, P. Supported graphene from natural resources: Easy preparation and applications. Adv. Mater. 2011, 23, 5250-5255. [CrossRef]

79. Darder, M.; Ruiz-Hitzky, E. Caramel-clay nanocomposites. J. Mater. Chem. 2005, 15, 3913-3918. [CrossRef]

80. Ruiz-Hitzky, E. Molecular access to intracrystalline tunnels of sepiolite. J. Mater. Chem. 2001, 11, 86-91. [CrossRef]

81. Wu, X.; Zhang, Q.; Liu, C.; Zhang, X.; Chung, D.D.L. Carbon-coated sepiolite clay fibers with acid pre-treatment as low-cost organic adsorbents. Carbon 2017, 123, 259-272. [CrossRef]

82. Yebra-Rodríguez, A.; Martín-Ramos, J.D.; Del Rey, F.; Viseras, C.; López-Galindo, A. Effect of acid treatment on the structure of sepiolite. Clay Miner. 2003, 38, 353-360. [CrossRef]

83. Aznar, A.J.; Sanz, J.; Ruiz-Hitzky, E. Mechanism of the grafting of organosilanes on mineral surfaces. IV. Phenylderivatives of sepiolite and poly (organosiloxanes). Colloid Polym. Sci. 1992, 270, 165-176. [CrossRef]

84. Gozález, L.; Ibarra, L.M.; Rodríguez, A.; Moya, J.S.; Valle, F.J. Fibrous silica gel obtained from sepiolite by $\mathrm{HCl}$ attack. Clay Miner. 1984, 19, 93-98. [CrossRef]

85. Ruiz-Hitzky, E.; Darder, M.; Aranda, P.; Del Burgo, M.Á.M.; Real, G. Del Bionanocomposites as new carriers for influenza vaccines. Adv. Mater. 2009, 21, 4167-4171. [CrossRef]

86. Alcântara, A.C.S.; Darder, M.; Aranda, P.; Tateyama, S.; Okajima, M.K.; Kaneko, T.; Ogawa, M.; Ruiz-Hitzky, E. Claybionanocomposites with sacran megamolecules for the selective uptake of neodymium. J. Mater. Chem. A 2014, 2, 1391-1399. [CrossRef]

87. Ruiz-García, C.; Pérez-Carvajal, J.; Berenguer-Murcia, A.; Darder, M.; Aranda, P.; Cazorla-Amorós, D.; Ruiz-Hitzky, E. Claysupported graphene materials: Application to hydrogen storage. Phys. Chem. Chem. Phys. 2013, 15, 18635-18641. [CrossRef]

88. Ruiz-García, C.; Darder, M.; Aranda, P.; Ruiz-Hitzky, E. Toward a green way for the chemical production of supported graphenes using porous solids. J. Mater. Chem. A 2017, 2009-2017. [CrossRef]

89. Liu, C.; Cai, W.; Liu, L. Applied Clay Science Hydrothermal carbonization synthesis of Al-pillared montmorillonite@carbon composites as high performing toluene adsorbents. Appl. Clay Sci. 2018, 162, 113-120. [CrossRef]

90. Gabriel, R.; Gonçalves, L.; De Carvalho, M.; Morais, R.; Andrade, E.; Frigi, G.; Macedo, S.; Augusto, M.; Regina, V.; Constantino, L.; et al. Mesoporous carbon derived from a biopolymer and a clay: Preparation, characterization and application for an organochlorine pesticide adsorption. Microporous Mesoporous Mater. 2016, 225, 342-354. [CrossRef] 
91. Benucci, I.; Liburdi, K.; Cacciotti, I.; Lombardelli, C.; Zappino, M.; Nanni, F.; Esti, M. Chitosan/clay nanocomposite films as supports for enzyme immobilization: An innovative green approach for winemaking applications. Food Hydrocoll. 2018, 74, 124-131. [CrossRef]

92. Hantanasirisakul, K.; Gogotsi, Y. Electronic and Optical Properties of 2D Transition Metal Carbides and Nitrides (MXenes). Adv. Mater. 2018, 30, 1804779. [CrossRef]

93. Wu, Z.; Deng, W.; Tang, S.; Ruiz-Hitzky, E.; Luo, J.; Wang, X. Pod-inspired MXene/porous carbon microspheres with ultrahigh adsorption capacity towards crystal violet. Chem. Eng. J. 2021, 426, 130776. [CrossRef]

94. Alves, Z.; Ferreira, N.M.; Mendo, S.; Ferreira, P.; Nunes, C. Design of Alginate-Based Bionanocomposites with Electrical Conductivity for Active Food Packaging. Int. J. Mol. Sci. 2021, 22, 9943. [CrossRef]

95. Barra, A.; Santos, J.D.C.; Silva, M.R.F.; Nunes, C.; Ruiz-Hitzky, E.; Gonçalves, I.; Yildirim, S.; Ferreira, P.; Marques, P.A.A.P. Graphene Derivatives in Biopolymer-Based Composites for Food Packaging Applications. Nanomaterials 2020, 10, 2077. [CrossRef] [PubMed]

96. Darder, M.; Aranda, P.; Ruiz-García, C.; Fernandes, F.M.; Ruiz-Hitzky, E. The Meeting Point of Carbonaceous Materials and Clays: Toward a New Generation of Functional Composites. Adv. Funct. Mater. 2017, 28, 1704323. [CrossRef] 